\title{
Determination of surface proteins profile, capsular genotyping, and antibiotic susceptibility patterns of Group B Streptococcus isolated from urinary tract infection of Iranian patients
}

\author{
Saba Jalalifar, Seyed Asghar Havaei, Tahereh Motallebirad, Sharareh Moghim, Hossein Fazeli \\ and Bahram Nasr Esfahani*
}

\begin{abstract}
Objectives: Group B Streptococcus (GBS) is an important opportunistic bacteria that causes a wide range of infections including neonatal sepsis, meningitis, pneumonia, soft tissue and urinary tract infections (UTI). The aim of this study was to evaluate the antimicrobial susceptibility patterns, surface proteins and capsular types of GBS isolates.

Results: 100 of UTI isolates were confirmed as GBS. Antimicrobial susceptibility pattern showed that 95\% of GBS isolates were resistant to tetracycline, followed by erythromycin (52\%), clindamycin (47\%), levofloxacin (9\%) and penicillin, cefepime, cefotaxime, and ceftriaxone each with (8\%), and vancomycin 1\%. Common capsular types were $\mathrm{III}, \mathrm{Ib}, \mathrm{V}, \mathrm{II}, \mathrm{la}$ and IV respectively and the distribution of surface protein genes was as follows: rib (40\%), alpha-c (22\%), alp2/3 (18\%) and epsilon (15\%), and alp4 gene was not detected in the isolates. Our findings showed the relationship between capsular types with Alpha-like proteins, as well as reduced sensitivity to antibiotics, so the performance of antibiotic surveillance programs is recommended.
\end{abstract}

Keywords: Antibiotic resistance, Surface protein, Multiplex PCR, Group B Streptococci, Urinary tract infection

\section{Introduction}

Streptococcus agalactiae, also known as Group B streptococcus (GBS), is a common commensal of the human gastrointestinal and genitourinary tracts [1]. In addition to causing a broad range of infectious diseases in neonates, pregnant women, the elderly and the immunocompromised, this organism is responsible for approximately $2-3 \%$ of all urinary tract infections (UTI) [2-4]. Diabetes mellitus, immunocompromised individuals and chronic renal failure may be risk factors for GBS UTI $[5,6]$. Therefore the study of the prevalence of GBS infections especially in populations with underlying

\footnotetext{
*Correspondence: nasr@hlth.mui.ac.ir
}

Department of Microbiology, School of Medicine, Isfahan University of Medical Sciences, Isfahan, Iran disease, contributes to epidemiological features of these infections.

With decreased in sensitivity of GBS to Penicillin in recent decade, Macrolides and lincosamides used as alternative therapeutic drugs against GBS [7-9]. Nevertheless, in recent years the resistance of $S$. agalactiae to macrolides, lincosamides and streptogramin B is being reported more often [10]. Hence determining the prevalence of antimicrobial susceptibility pattern of GBS in different regions is important for therapeutic strategy.

The pathogenic mechanisms that underlie acute UTI due to GBS are associated with different virulence factors including Surface-expressed protein adhesion molecules, immune-evasion factors and toxins [11]. The major virulence factors of GBS are the capsular polysaccharide (cps) that is involved in virulence and immune evasion and 
surface proteins having participated in GBS pathogenesis and immunization.

cps type of a GBS strain determines the serotype and these different serotypes have been linked to virulence [12]. This makes it possible to used cps as an epidemiological marker for typing of GBS.

Based on epidemiologic and pathogenic studies, GBS expresses a ten different serotype variants (i.e., Ia, Ib, II, III, IV, V VI, VII, VIII, and IX) capsular polysaccharide that is involved in virulence and immune evasion, which these serotypes differ in their disease-causing abilities $[8$, 13].

The major surface-localized protein antigens belongs to alpha-like protein (Alp) family and Alpha-C protein, Rib, Alp2, Alp3, Alp4 and the Epsilon protein. They characterized by internal long identical tandem repeats which have an important role in GBS pathogenesis and are considered to be vaccine candidates $[8,14]$. Hence, serologic profile of isolates, applied PCR amplification of CPS and surface-localized protein genes of GBS, it is useful to typing the isolates with good discriminatory power and is applicable in diagnosis, treatment and control of this infectious agent.

The aim of this study was to characterize the antibiotic susceptibility patterns, capsular type and surface proteins distribution of GBS isolated from urine samples of patients referring to the educational hospitals of Isfahan, Iran.

\section{Main text Methods}

From June 2017 to November 2017 a total of 100 Urine isolates were collected from 2 male and 98 female patients across different age groups who underwent assessment for UTI. The samples that referred in the clinical microbiology laboratory were cultured on 5\% sheepblood agar and incubated overnight at $37{ }^{\circ} \mathrm{C}$ (Biolife, Italian). The isolates were characterized phenotypically as S. agalactiae by the use of conventional phenotypic and biochemical tests included; Gram staining, colony morphology, catalase, oxidase and CAMP test (Additional file 1) and the confirmed isolates were stored at $-80^{\circ} \mathrm{C}$ in brain heart infusion (BHI) broth containing $20 \%$ glycerol.

Antimicrobial susceptibility testing was performed based on disk diffusion method on Mueller-Hinton agar with sheep blood (5\% v/v) (Himedia, India), in accordance to the Clinical and Laboratory Standards Institute (CLSI) guidelines (2017). Commercially prepared and dehydrated antibiotic discs used in the study were as follows: clindamycin $(2 \mu \mathrm{g})$, vancomycin $(30 \mu \mathrm{g})$, erythromycin $(15 \mu \mathrm{g})$, penicillin (10 units), tetracycline $(30 \mu \mathrm{g})$, cefepime $(30 \mu \mathrm{g})$, cefotaxime $(30 \mu \mathrm{g})$, ceftriaxone $(30 \mu \mathrm{g})$, levofloxacin $(5 \mu \mathrm{g})$; disks (MAST, Merseyside, UK). $S$. aureus ATCC 25923 was also used as the quality control. The strain non-susceptible to $\geq 1$ antibiotic at least three of antibiotics categories were characterized as MDR.

The MIC for penicillin non-susceptible isolates were determined using the Etest ${ }^{\circledR}$ strip (Liofilchem, Italy 0/002-3 mg/L). The clindamycin-induced resistance was detected in GBS isolates resistant to erythromycin, but susceptible to clindamycin by the double-disc diffusion method (D-zone test) [15].

Chromosomal DNA was extracted using a phenolchloroform method with some modifications [16]. For the lysis of $S$. agalactiae cells, a pretreatment with higher concentrations of lysozyme $(200 \mathrm{mg} / \mathrm{ml}$ final concentration) and proteinase $\mathrm{K}(300 \mathrm{mg} / \mathrm{ml}$ final concentration) in the presence of sodium dodecyl sulfate (SDS). The extracted DNA was purified with chloroform-isoamyl alcohol (24:1, $\mathrm{vol} / \mathrm{vol}), \quad$ phenol-chloroform-isoamyl alcohol $(25: 24: 1, \mathrm{vol} / \mathrm{vol} / \mathrm{vol})$ and then precipitated with sodium acetate and ethanol at $-20^{\circ} \mathrm{C}$. Precipitated DNA was washed with $70 \%$ ethanol and resuspended in $100 \mu \mathrm{l}$ of Milli-Q water.

The urine isolates identified phenotypically as $S$. agalactiae were further analyzed to the species confirmation using the PCR amplification of $d l t S$ gene.

The identification of capsular genotypes (Ia, Ib and II to IX) of all GBS isolates was performed by multiplex PCR assay as previously described [17]. capsular type of isolates were identified by analyzing the unique banding pattern following agarose gel $1.5 \%(\mathrm{w} / \mathrm{v})$ electrophoresis and Non-typeable isolates were designated as NT. GBSspecific $d l t S$ gene was used as internal positive control.

A multiplex PCR assay was applied for direct identification of GBS alpha-protein-like genes, $b c a, r i b$, epsilon, alp $2 / 3$ and alp 4 with five pairs of primers according to the procedure of Creti et al. [14]. In brief, The PCR program was performed by first denaturation at $94{ }^{\circ} \mathrm{C}$ for $5 \mathrm{~min}$, followed by 35 cycles of denaturation at $94{ }^{\circ} \mathrm{C}$ for $30 \mathrm{~s}$, primer annealing at $56{ }^{\circ} \mathrm{C}$ for $30 \mathrm{~s}$ and extension at $72{ }^{\circ} \mathrm{C}$ for $45 \mathrm{~s}$, and a final extension at $72{ }^{\circ} \mathrm{C}$ for $5 \mathrm{~min}$. Positive control was confirmed by direct sequencing of the PCR products of positive GBS isolate.

The SPSS Statistics (IBM SPSS Statistics for Windows, V.20.) was used for statistical analysis. Chi square tests were determined to define possible associations between the variables. $p<0.050$ were regarded as statistically significant.

\section{Results}

In the present study a total of 100 confirmed S. agalactiae isolates were recovered from patients with UTI. A total of 98 GBS isolates (98\%) were obtained from female [69 (70.4\%) non-pregnant, 9 (9.2\%) pre-pregnant and 
$20(20.4 \%)$ pregnant] and $2 \%$ were obtained from male patients.

The results of antimicrobial susceptibility testing based on disk diffusion method indicated that $8 \%$ of GBS isolates were resistant to penicillin and MIC of these isolates was confirmed by Etest (non-susceptible, MICs $>0.12$ ). $95 \%$ of isolates were resistant to tetracycline, followed by erythromycin $(52 \%)$ and clindamycin $(47 \%)$. Also $22 \%$ of isolates were recorded as having intermediate resistance to erythromycin and $8 \%$ of isolates for clindamycin, while, most of the isolates were sensitive to vancomycin (99\%). Simultaneous resistance to both clindamycin and erythromycin was found in $38 \%$ of isolates.

Also, the rate of MDR isolates was estimated at $46 \%$. However, the frequency of MDR isolates was higher among penicillin-resistance isolates than penicillinsusceptible but were not significant $(100 \%$ vs. $41.3 \%$, $p>0.05$ ).

The multiplex PCR assay of capsular type GBS revealed that all our isolates were grouped in six serotypes. The GBS capsular serotype isolated from UTI infection in this study were as followed; Serotypes III $(n=41,41 \%)$, serotypes Ib (24\%), V (18\%), II (7\%), Ia (4\%) and IV (2\%). Only $4 \%$ of isolates were initially classified as non-typeable. Serotypes VI, VII, VIII and IX were not detected in this study (Table 1).

Out of 100 isolates, $99 \%$ have surface protein antigen genes as follow: rib (40\%), alpha-c (22\%), alp2/3 (18\%) and epsilon (15\%), although alp4 gene was not detected in the isolates. Three isolates were positive for both alpha-c and alp $2 / 3$ of genes, and one isolate was positive for both alpha-c and rib of genes. Only one GBS isolate did not harbor any of the genes from the alpha family (Table 1). Also a significant relationship was observed between antibiotic resistance, capsular types and surface protein genes (Table 2).

\section{Discussion}

Streptococcus agalactiae has been known, since the 1970s, and it is frequently found in the genitourinary and the gastrointestinal tracts, but it is also the predominant cause of neonatal infection and recently was accounted as an important etiological agent in immunocompromised and elderly patients $[2,18]$. The most important factors involved in virulence of GBS are the capsular polysaccharide (cps) and surface protein antigen $[15,19]$. Due to the geographical distribution and high diversity of type of the CPS and surface protein antigens, they could be used as an appropriate marker for epidemiology studies [20]. Epidemiological studies have demonstrated the predominance of particular serotypes in the invasive and noninvasive infections, furthermore geographical variations in the distribution of serotypes as well as the emergence of particular clones have been noted [21, 22]. In this field, the knowing the data of circulating serotypes and their characteristics in relation to the virulence properties are accounted an effective instrument in control of infections caused by GBS [23]. According to previous study, the correct identification of the cps types is crucial in the design of a broad coverage glycoconjugate vaccine which would

Table 1 Distribution of the capsular types and alp genes among the urinary GBS isolates

\begin{tabular}{|c|c|c|c|c|c|c|c|}
\hline \multirow{2}{*}{$\begin{array}{l}\text { Surface alpha-like protein genes } \\
\text { No. of isolates (\%) }\end{array}$} & \multicolumn{7}{|c|}{ No. of isolates (\%) of serotypes } \\
\hline & $\begin{array}{l}\text { la } \\
\mathrm{n}=4\end{array}$ & $\begin{array}{l}\mathrm{lb} \\
\mathrm{n}=24\end{array}$ & $\begin{array}{l}\text { II } \\
n=7\end{array}$ & $\begin{array}{l}\text { III } \\
n=41\end{array}$ & $\begin{array}{l}\text { IV } \\
n=2\end{array}$ & $\begin{array}{l}V \\
n=18\end{array}$ & $\begin{array}{l}\text { NT } \\
\mathrm{n}=4\end{array}$ \\
\hline $\begin{array}{l}r i b \\
n=40(\%)\end{array}$ & $2(5)$ & $0^{* *}$ & $2(5)$ & $34(85) * *$ & - & $1(2.5) * *$ & $1(2.5)$ \\
\hline $\begin{array}{l}\text { alpha-cprotein } \\
\mathrm{n}=22(\%)\end{array}$ & - & $18(81.8) * *$ & $1(4.5)$ & $0^{* *}$ & - & $3(13.6)$ & - \\
\hline 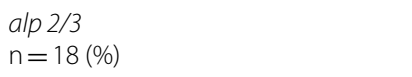 & - & $3(16.7)$ & $1(5.6)$ & $6(33.3)$ & $1(5.6)$ & $7(38.9) *$ & - \\
\hline $\begin{array}{l}\text { epsilon } \\
\mathrm{n}=15(\%)\end{array}$ & $2(13.3) *$ & $0^{*}$ & $3(20) *$ & $0^{* *}$ & $1(6.7)$ & $6(40) *$ & $3^{* *}(20)$ \\
\hline $\begin{array}{l}\text { alp4 } \\
\mathrm{n}=0(\%)\end{array}$ & - & - & - & - & - & - & - \\
\hline $\begin{array}{l}\text { alpha-c protein }+ \text { alp } 2 / 3 \\
n=3(\%)\end{array}$ & - & $2(66.6)$ & - & - & - & $1(33.3)$ & - \\
\hline $\begin{array}{l}\text { alpha-cprotein + rib } \\
\mathrm{n}=1(\%)\end{array}$ & - & - & - & 1 (100) & - & - & - \\
\hline $\begin{array}{l}\text { NT } \\
\mathrm{n}=1(\%)\end{array}$ & - & $1(100)$ & - & - & - & - & - \\
\hline
\end{tabular}


Table 2 Distribution of serotype and alp genes among urinary GBS isolates across resistant isolates

\begin{tabular}{|c|c|c|c|c|c|c|c|c|c|}
\hline \multirow[t]{2}{*}{ Serotype } & \multicolumn{9}{|c|}{ No. of resistant isolates (\%) } \\
\hline & $\begin{array}{l}\text { Penicillin } \\
n=8(\%)\end{array}$ & $\begin{array}{l}\text { Erythromycin } \\
n=52(\%)\end{array}$ & $\begin{array}{l}\text { Clindamycin } \\
n=47(\%)\end{array}$ & $\begin{array}{l}\text { Tetracycline } \\
\mathrm{n}=95(\%)\end{array}$ & $\begin{array}{l}\text { Vancomycin } \\
n=1(\%)\end{array}$ & $\begin{array}{l}\text { Levofloxacin } \\
\mathrm{n}=9(\%)\end{array}$ & $\begin{array}{l}\text { Cefotaxime } \\
n=8(\%)\end{array}$ & $\begin{array}{l}\text { Ceftriaxone } \\
n=8(\% 0\end{array}$ & $\begin{array}{l}\text { Cefepime } \\
n=8(\%)\end{array}$ \\
\hline la & - & $2(3.8)$ & - & $4(4.2)$ & - & $1(11.1)$ & - & - & - \\
\hline 16 & $2(25)$ & $22(42.3)^{* *}$ & $23(48.9)^{* *}$ & $24(25.3)$ & - & $1(11.1)$ & $2(25)$ & $2(25)$ & $2(25)$ \\
\hline "I & - & $3(5.8)$ & $1(2.1)$ & $7(7.4)$ & - & $1(11.1)$ & - & - & - \\
\hline III & $0^{*}$ & $8(15.4)^{* *}$ & $8(17)^{* *}$ & $40(42.1)$ & - & $0^{* *}$ & $0^{*}$ & $0^{*}$ & $0^{*}$ \\
\hline IV & - & $2(3.8)$ & $2(4.3)$ & $1(1.1)^{* *}$ & - & - & - & - & - \\
\hline V & $2(25)$ & $12(23.1)$ & $9(19.1)$ & $16(16.8)$ & - & $5(55.6)^{* *}$ & $2(25)$ & $2(25)$ & $2(25)$ \\
\hline NT & $4(50)^{* *}$ & $3(5.8)$ & $4(8.5)$ & $3(3.2)$ & $1(100)^{* *}$ & $1(11.1)$ & $4(50)^{* *}$ & $4(50)^{* *}$ & $4(50)^{* *}$ \\
\hline \multicolumn{10}{|l|}{ alp gene } \\
\hline rib & $1(12.5)$ & $8(15.4)^{* *}$ & $8(17)^{* *}$ & $40(42.1)$ & $1(100)$ & $1(11.1)$ & $1(12.5)$ & $1(12.5)$ & $1(12.5)$ \\
\hline $\begin{array}{l}\text { alpha-c } \\
\text { protein }\end{array}$ & $2(25)$ & $20(38.5)^{* *}$ & $21(44.7)^{* *}$ & $22(23.1)$ & - & $1(11.1)$ & $2(25)$ & $2(25)$ & $2(25)$ \\
\hline alp 2/3 & - & $9(17.3)$ & $9(19.1)$ & $16(16.8)$ & - & - & - & - & - \\
\hline epsilon & $3(37.5)$ & $12(23.1)^{*}$ & $5(10.6)$ & $13(13.7)$ & - & $6(66.7)^{* *}$ & $3(37.5)$ & $3(37.5)$ & $3(37.5)$ \\
\hline alp4 & - & - & - & - & - & - & - & - & - \\
\hline $\begin{array}{l}\text { alpha-c pro- } \\
\text { tein }+ \text { alp } \\
2 / 3\end{array}$ & $2(25)^{* *}$ & $2(3.8)$ & $3(6.4)$ & $3(3.2)$ & - & $1(11.1)$ & $2(25)$ & $2(25)$ & $2(25)$ \\
\hline $\begin{array}{c}\text { alpha-c pro- } \\
\text { tein + rib }\end{array}$ & - & - & - & $0^{* *}$ & - & - & - & - & - \\
\hline NT & - & $1(1.9)$ & $1(2.1)$ & $1(1.1)$ & - & - & - & - & - \\
\hline
\end{tabular}

${ }^{*} p<0.05$

** $p<0.01$

support the most disseminated cps types with GBS surface exposed-antigens, as the Alpha-like proteins that have been demonstrate as promising vaccine candidates [24]. Penicillin is the first-line agents for both prophylaxis and treatment of $S$. agalactiae infections, although several studies have demonstrated the reduced susceptibility to penicillin against GBS infections $[25,26]$. These findings demonstrated that frequencies of PRGBS in S. agalactiae from Isfahan have some differences from those that have been reported in other geographic regions. According to our observations, $8 \%$ of GBS isolates were PRGBS. While, it was higher than reports from Northwest Iran (1.7\%) [27], and lower than reports from Seki et al. Japan (14.7\%) [28].

In the current study, vancomycin was the most effective antibiotic agent with the susceptibility rate of $99 \%$. Simoes et al. from Brazil and Shabayekt et al. from Egypt, reported susceptibility rate $100 \%[29,30]$. In our findings, the rate of resistance to tetracycline was $95 \%$ which was slightly lower than reports from Brazil (97\%) [22] and Tunisia (97.3\%) [31]. Our data demonstrated that the resistance rate for both erythromycin and clindamycin were $52 \%$ and $47 \%$, respectively. The rates of resistance to erythromycin and clindamycin were higher than Studies conducted in Malaysia [15, 32]. While, in another study carried out by Guoet al. from China, higher resistance was described for erythromycin $(63 \%)$ and lower resistance was described for clindamycin (44\%) [33]. According to the previous findings from Brazil and Malaysia, all of the isolates were susceptible to cephalosporins [1, 15], whereas, our results showed a higher resistance to cephems groups as reports Jannati et al. from Northwest, Iran [27]. This organism expresses capsular polysaccharides that are important virulence factors, epidemiological markers and are the main components of conjugate vaccines. The capsular types of $96 \%$ isolates were identified, in this study. Six serotypes (Ia, Ib, II, III, IV, V) were detected and the serotype III was the most common type (41\%), which was different to that previously described in Tabriz, Northwest Iran by Nahaei et al. [34] but was similar to those reported in Kashan [35], China [21], Portugal [9] and America [36]. alp Genes have an important role in GBS pathogenesis and are also conjugate vaccine candidates with CPS. Approximately most of GBS strains possess one of alp genes. Our multiplex PCR analysis results showed that the frequency of rib in GBS isolates was $40 \%$, as predominant type that was similar to other geographical regions of Iran, Chinaand Italy $[3,37,38]$. Only $1 \%$ of the tested isolates were negative for any existing alp genes and $4 \%$ were positive for two genes. In our 
finding, a significant relationship was observed between serotypes and surface protein genes. However, it should be reiterated that the isolates studied in this study, contrary to other studies conducted in Iran, have been related to urinary tract infection.

In summary, our results showed reduced sensitivity to antibiotics, especially against penicillin in S. agalactiae isolates which may be related to inappropriate and excessive administration of these antibiotics in patients, therefore, monitoring and control in the administration of antimicrobial agents and better awareness of the source of antibiotic resistance is recommended. In addition, most of our isolates were distributed to capsular serotype III, Ib and V and rib and alpha-c as surface protein antigen genes are more prevalent than other surface protein.

\section{Limitation}

Although the distribution of surface proteins of GBS strains will be useful in epidemiological studies and design of vaccines; but further genetic research on a larger number of GBS isolates is necessary for epidemiological investigation and vaccine development.

\section{Additional file}

Additional file 1. CAMP test.

\section{Abbreviations}

SDS: sodium dodecyl sulfate; D-zone test: double-disc diffusion method; CLSI: Clinical and Laboratory Standards Institute; TSB: Tryptic Soy Broth; Alp: alphalike protein; cps: capsular polysaccharide; ABU: asymptomatic bacteriuria; UTI: urinary tract infections; GBS: Group B Streptococcus.

\section{Acknowledgements}

We are thankful to all members of Department of Microbiology, School of Medicine, at Isfahan University of Medical Sciences.

\section{Authors' contributions}

SJ, SAH, TM, SM, HF, BNE: Designed and supervised, collected and analyzed the data and drafted the manuscript. All authors read and approved the final manuscript.

\section{Funding}

The authors are grateful to office of vice-chancellor for Research of Isfahan University of Medical Sciences (396622) for the support of the current study

\section{Availability of data and materials}

The datasets used and/or analyzed during the current study are available from the corresponding author on reasonable request

\section{Ethics approval and consent to participate}

The study protocol was approved by the Ethics Committee of Isfahan University of Medical Sciences (IR.MUI.REC.1396.3.622). However, we did not have human participants. The study used bacteria isolated from clinical samples in the clinical microbiology laboratory.

\section{Consent for publication}

Not applicable.

\section{Competing interests}

The authors declare that they have no competing interests.

Received: 27 March 2019 Accepted: 5 July 2019

Published online: 19 July 2019

\section{References}

1. Otaguiri ES, Morguette AEB, Tavares ER, dos Santos PMC, Morey AT, Cardoso JD, Perugini MRE, Yamauchi LM, Yamada-Ogatta SF. Commensal Streptococcus agalactiae isolated from patients seen at University Hospital of Londrina, Paraná, Brazil: capsular types, genotyping, antimicrobial susceptibility and virulence determinants. BMC Microbiol. 2013;13:297.

2. Sullivan MJ, Carey AJ, Leclercq SY, Tan CK, Ulett GC. Increased age, but not parity predisposes to higher bacteriuria burdens due to streptococcus urinary tract infection and influences bladder cytokine responses, which develop independent of tissue bacterial loads. PLoS ONE. 2016;11:e0167732.

3. Piccinelli G, Biscaro V, Gargiulo F, Caruso A, De Francesco MA. Characterization and antibiotic susceptibility of Streptococcus agalactiae isolates causing urinary tract infections. Infect Genet Evol. 2015;34:1-6.

4. Ulett KB, Benjamin WH Jr, Zhuo F, Xiao M, Kong F, Gilbert GL, Schembri MA, Ulett GC. Diversity of group B streptococcus serotypes causing urinary tract infection in adults. J Clin Microbiol. 2009;47:2055-60.

5. Kline KA, Lewis AL. Gram-positive uropathogens, polymicrobial urinary tract infection, and the emerging microbiota of the urinary tract. Microbiol Spectr. 2016;4:2.

6. Falagas ME, Rosmarakis ES, Avramopoulos I, Vakalis N. Streptococcus agalactiae infections in non-pregnant adults: single center experience of a growing clinical problem. Med Sci Monit. 2006;12:447-51.

7. Longtin J, Vermeiren C, Shahinas D, Tamber GS, McGeer A, Low DE, Katz K, Pillai D. Novel mutations in a patient isolate of Streptococcus agalactiae with reduced penicillin susceptibility emerging after long term oral suppressive therapy. Antimicrob Agents Chemother. 2011;55:2983-5.

8. Sadowy E, Matynia B, Hryniewicz W. Population structure, virulence factors and resistance determinants of invasive, non-invasive and colonizing Streptococcus agalactiae in Poland. J Antimicrob Chemother. 2010:65:1907-14.

9. Florindo C, Viegas S, Paulino A, Rodrigues E, Gomes JP, Borrego MJ. Molecular characterization and antimicrobial susceptibility profiles in Streptococcus agalactiae colonizing strains: association of erythromycin resistance with subtype III-1 genetic clone family. Clin Microbiol Infect. 2010;16:1458-63.

10. Brzychczy-Włoch M, Gosiewski T, Bodaszewska M, Pabian W, Bulanda M, Kochan P, Strus M, Heczko PB. Genetic characterization and diversity of Streptococcus agalactiae isolates with macrolide resistance. J Med Microbiol. 2010;59:780-6.

11. Udo EE, Boswihi SS, Al-Sweih N. Genotypes and virulence genes in group B streptococcus isolated in the maternity hospital, Kuwait. Med Princ Pract. 2013;22:453-7.

12. Imperi M, Pataracchia M, Alfarone $G$, Baldassarri L, Orefici G, Creti R. A multiplex PCR assay for the direct identification of the capsular type (la to IX) of Streptococcus agalactiae. J Microbiol Methods. 2010;80:212-4.

13. Sheppard AE, Vaughan A, Jones N, Turner P, Turner C, Efstratiou A, Patel D, Walker AS, Berkley JA, Crook DW. Capsular typing method for Streptococcus agalactiae using whole genome sequence data. J Clin Microbiol. 2016;54:03142-55.

14. Creti R, Fabretti F, Orefici G, von Hunolstein C. Multiplex PCR assay for direct identification of group B streptococcal alpha-protein-like protein genes. J Clin Microbiol. 2004;42:1326-9.

15. Eskandarian N, Ismail Z, Neela V, van Belkum A, Desa MN, Amin Nordin S. Antimicrobial susceptibility profiles, serotype distribution and virulence determinants among invasive, non-invasive and colonizing Streptococcus agalactiae (group B streptococcus) from Malaysian patients. Eur J Clin Microbiol Infect Dis. 2015;34:579-84

16. Green MR, Sambrook J. Isolation of high-molecular-weight DNA using organic solvents. Cold Spring Harb Protoc. 2017;2017:93450. 
17. Poyart C, Tazi A, Réglier-Poupet H, Billoët A, Tavares N, Raymond J, TrieuCuot P. Multiplex PCR assay for rapid and accurate capsular typing of group B streptococci. J Clin Microbiol. 2007;45:1985-8.

18. Wang $\mathrm{Y}-\mathrm{H}$, Chen $\mathrm{H}-\mathrm{M}$, Yang $\mathrm{Y}-\mathrm{H}$, Yang $\mathrm{T}-\mathrm{H}$, Teng $\mathrm{C}-\mathrm{H}$, Chen $\mathrm{C}-\mathrm{L}$, Chu $\mathrm{C}$, Chiu C-H. Clinical and microbiological characteristics of recurrent group B streptococcal infection among non-pregnant adults. Int J Infect Dis. 2014;26:140-5

19. Afshar B, Broughton $K$, Creti R, Decheva A, Hufnagel M, Kriz P, Lambertsen L, Lovgren M, Melin P, Orefici G. International external quality assurance for laboratory identification and typing of Streptococcus agalactiae (Group B streptococci). J Clin Microbiol. 2011;49:1475-82.

20. Lachenauer C, Creti R, Michel J, Madoff L. Mosaicism in the alpha-like protein genes of group B streptococci. Proc Natl Acad Sci. 2000;97:9630-5.

21. Yan Y, Hu H, Lu T, Fan H, Hu Y, Li G, Zhang X, Shi Y, Xia R. Investigation of serotype distribution and resistance genes profile in group B Streptococcus isolated from pregnant women: a Chinese multicenter cohort study. Apmis. 2016;124:794-9.

22. Dutra VG, Alves VM, Olendzki AN, Dias CA, de Bastos AF, Santos GO, de Amorin EL, Sousa MÂ, Santos R, Ribeiro PC. Streptococcus agalactiae in Brazil: serotype distribution, virulence determinants and antimicrobial susceptibility. BMC Infect Dis. 2014;14:323.

23. Dore N, Bennett D, Kaliszer M, Cafferkey M, Smyth C. Molecular epidemiology of group B streptococci in Ireland: associations between serotype invasive status and presence of genes encoding putative virulence factors. Epidemiol Infect. 2003;131:823-33.

24. Kong F, Gowan S, Martin D, James G, Gilbert GL. Molecular profiles of group B streptococcal surface protein antigen genes: relationship to molecular serotypes. J Clin Microbiol. 2002;40:620-6.

25. Dahesh S, Hensler ME, Van Sorge NM, Gertz RE Jr, Schrag S, Nizet V, Beall BW. Point mutation in the group B streptococcal pbp2x gene conferring decreased susceptibility to beta-lactam antibiotics. Antimicrob Agents Chemother. 2008;52:2915-8.

26. Kimura K, Suzuki S, Wachino J, Kurokawa H, Yamane K, Shibata N, Nagano $\mathrm{N}$, Kato H, Shibayama K, Arakawa Y. First molecular characterization of group B streptococci with reduced penicillin susceptibility. Antimicrob Agents Chemother. 2008;52:2890-7.

27. Jannati E, Roshani M, Arzanlou M, Habibzadeh S, Rahimi G, Shapuri R. Capsular serotype and antibiotic resistance of group B streptococci isolated from pregnant women in Ardabil, Iran. Iran J Microbiol. 2012:4:130-5

28. Seki T, Kimura K, Reid ME, Miyazaki A, Banno H, Jin W, Wachino J, Yamada $\mathrm{K}$, Arakawa Y. High isolation rate of MDR group $B$ streptococci with reduced penicillin susceptibility in Japan. J Antimicrob Chemother. 2015:70:2725-8
29. Simoes JA, Aroutcheva AA, Heimler I, Faro S. Antibiotic resistance patterns of group B streptococcal clinical isolates. Infect Dis Obstet Gynecol. 2004:12:1-8.

30. Shabayek S, Abdalla S. Macrolide- and tetracycline-resistance determinants of colonizing group B streptococcus in women in Egypt. J Med Microbiol. 2014;63:1324-7.

31. Hraoui M, Boutiba-Ben Boubaker I, Rachdi M, Slim A, Ben Redjeb S. Macrolide and tetracycline resistance in clinical strains of Streptococcus agalactiae isolated in Tunisia. J Med Microbiol. 2012:61:1109-13.

32. Suhaimi MES, Desa MNM, Eskandarian N, Pillay SG, Ismail Z, Neela VK, Masri SN, Nordin SA. Characterization of a Group B Streptococcus infection based on the demographics, serotypes, antimicrobial susceptibility and genotypes of selected isolates from sterile and non-sterile isolation sites in three major hospitals in Malaysia. J Infect Public Health 2017;10:14-21.

33. Guo Y, Deng $X$, Liang Y, Zhang L, Zhao GP, Zhou Y. The draft genomes and investigation of serotype distribution, antimicrobial resistance of group B Streptococcus strains isolated from urine in Suzhou, China. Ann Clin Microbiol Antimicrob. 2018;17:28

34. Nahaei MR, Ghandchilar N, Bilan N, Ghahramani P. Maternal carriage and neonatal colonization of Streptococcus agalactiae in Tabriz, Northwest Iran. Iran J Med Sci. 2015;32:177-81.

35. Yasini M, Samadi R, Moniri R, Mirzaee H. Serotype distribution and antimicrobial resistance pattern of GroupB Streptococcus isolated from pregnant women. IJAPBS. 2016;5:15-21.

36. Madzivhandila M, Adrian PV, Cutland CL, Kuwanda L, Schrag SJ, Madhi SA Serotype distribution and invasive potential of group B streptococcus isolates causing disease in infants and colonizing maternal-newborn dyads. PLoS ONE. 2011;6:e17861.

37. Sadeh M, Firouzi R, Derakhshandeh A, Khalili MB, Kong F, Kudinha T. Molecular characterization of Streptococcus agalactiae isolates from pregnant and non-pregnant women at Yazd University Hospital, Iran. Jundishapur J Microbiol. 2016:9:2.

38. Lu B, Chen X, Wang J, Wang D, Zeng J, Li Y, Li D, Zhu F, Cui Y, Huang L. Molecular characteristics and antimicrobial resistance in invasive and noninvasive Group B Streptococcus between 2008 and 2015 in China. Diagn Microbiol Infect Dis. 2016;86:351-7.

\section{Publisher's Note}

Springer Nature remains neutral with regard to jurisdictional claims in published maps and institutional affiliations.
Ready to submit your research? Choose BMC and benefit from:

- fast, convenient online submission

- thorough peer review by experienced researchers in your field

- rapid publication on acceptance

- support for research data, including large and complex data types

- gold Open Access which fosters wider collaboration and increased citations

- maximum visibility for your research: over 100M website views per year

At BMC, research is always in progress.

Learn more biomedcentral.com/submissions 